\title{
BEBERAPA ASPEK PENTING DALAM BUDIDAYA UDANG VANAMEI (Litopenaeus vannamei) DENGAN SISTEM PEMUPUKAN SUSULAN DI TAMBAK (TRADISIONAL PLUS)
}

\author{
Gunarto*) \\ *) Balai Riset Perikanan Budidaya Air Payau, Maros
}

\begin{abstract}
ABSTRAK
Sebagian besar tambak di Indonesia dikelola secara tradisional oleh petambak yang rata-rata bermodal kecil. Untuk itu, teknologi budidaya udang vanamei pola tradisional plus perlu dikembangkan misalnya dengan sistem pemupukan susulan sehingga akan diperoleh teknologi budidaya yang murah tetapi menguntungkan bagi petambak tradisional. Beberapa faktor penting yang sangat perlu diperhatikan agar supaya berhasil dalam budidaya udang vanamei pola tradisional plus, di antaranya adalah persiapan tambak harus maksimal, pemilihan dan penanganan benur harus betul, kontruksi tambak meskipun untuk pola tradisional harus didisain agar air baru mudah masuk ke tambak dan air buangan beserta limbahnya dapat segera keluar dari pelataran tambak, cara pengelolaan air sistem resirkulasi atau penggantian air hanya dilakukan saat terjadi air pasang tinggi. Penggunaan fermentasi probiotik dan peningkatan upaya biosekuritas di sekitar lingkungan tambak. Dengan memperhatikan faktor-faktor penting tersebut, meskipun udang dipelihara pada musim kemarau dengan kadar garam tinggi (53-- 34 ppt) dengan hanya mengandalkan pemupukan susulan $750 \mathrm{~g}$ urea dan $375 \mathrm{~g}$ SP$36 / 500 \mathrm{~m}^{2}$ serta penambahan fermentasi probiotik sebanyak $3 \mathrm{mg} / \mathrm{L}$ per minggu ternyata masih bisa panen dengan masa pemeliharaan lebih singkat yaitu 76 hari. Produksi pada kepadatan 1, 3, 5, dan 7 ekor $/ \mathrm{m}^{2}$ masing-masing pada kisaran $4,1--8,69 \mathrm{~kg} / 500 \mathrm{~m}^{2}(82--173,8$ $\mathrm{kg} / \mathrm{ha}) ; 8,7--10,7 \mathrm{~kg} / 500 \mathrm{~m}^{2}(174--214 \mathrm{~kg} / \mathrm{ha})$; 4,27-- $10,55 \mathrm{~kg} / 500 \mathrm{~m}^{2}(175,6--211 \mathrm{~kg} / \mathrm{ha}) ;$ dan $11,6--17,5$ kg/500 m² (232-- $350 \mathrm{~kg} / \mathrm{ha})$.
\end{abstract}

KATA KUNCl: budidaya, pola tradisional, pemupukan susulan

\section{PENDAHULUAN}

Banyaknya peristiwa gagal panen pada budidaya udang windu baik yang intensif maupun tradisional di tambak, mendorong pemerintah mengijinkan untuk budidaya udang vanamei yang berasal dari Amerika Latin. Untuk produksi benih, induk udang vanamei SPF (Spesific Pathogen Free) didatangkan dari Hawaii. Teknologi intensif budidaya udang vanamei di tambak saat ini telah maju, misalnya di Lampung, Banyuwangi, Situbondo, Lamongan di Jawa Timur, Lombok, Sukabumi di Jawa Barat, serta Bulukumba dan Barru di Sulawesi Selatan. Keberhasilan budidaya tersebut telah mampu mendongkrak naik produksi udang Indonesia. Namun demikian $90 \%$ dari luas tambak di Indonesia adalah tambak yang dikelola secara tradisional baik untuk budidaya ikan bandeng ataupun udang windu. Oleh karena itu, budidaya udang vanamei pola tradisional plus perlu dikembangkan guna mendukung program revitalisasi tambak dan sekaligus mampu meningkatkan pendapatan petambak tradisional.

Di beberapa lokasi seperti di Banyuwangi dan Lamongan para petambak telah mulai merintis upaya budidaya udang vanamei pola tradisional plus, namun masih perlu dilakukan penelitian guna mendapatkan teknologi yang tepat, efisien, dan menguntungkan. Satu di antara upaya tersebut adalah dengan penyediaan pakan alami yang cukup dan berkesinambungan, dengan cara pemupukan. Dengan menambah unsur hara secara periodik melalui pemupukan dalam jumlah tertentu kedalam perairan akan merangsang pertumbuhan fitoplankton sehingga mempengaruhi kesuburan perairan. Dosis pupuk urea dan TSP pada pemupukan awal yang biasa digunakan adalah 150--200 kg urea dan 75--100 kg TSP/ha (Amin \& Wikanta, 1989; Andarias, 1991). Berdasarkan penelitian pendahuluan Gunarto et al. (2006) mendapatkan bahwa pemupukan susulan sebanyak $10 \%$ dari dosis pemupukan awal dan diberikan sekali setiap 1--2 minggu selama pemeliharaan berlangsung, menghasilkan pertumbuhan udang yang cenderung lebih baik daripada dosis $5 \%$ dan 7,5\%dari dosis pupuk awal.

Pada tahun 2005 dan terus berlanjut hingga 2006, kasus penyakit mulai nampak pada udang vanamei yang 
dibudidayakan di tambak baik dengan pola intensif maupun tradisional khususnya di Sulawesi Selatan dan menyebabkan kematian massal seperti halnya pada udang windu. Analisis dengan PCR pada udang vanamei yang sakit ternyata udang tersebut terinfeksi WSSV. Dengan demikian permasalahannya adalah sama dengan yang dihadapi pada udang windu yaitu tidak mampu bertahan dari serangan WSSV. Sehingga dalam budidaya udang vanamei perlu ada strategi untuk memahami aspek-aspek penting yang dapat meminimalisir munculnya serangan WSSV ataupun jenis penyakit lainnya. Dengan demikian tidak hanya ketersediaan pakan secara berkelanjutan yang menentukan keberhasilan budidaya udang vanamei di tambak pola tradisional plus, tetapi juga mutu dan penanganan benur sebelum tebar, kontruksi tambak, pengelolaan air, dan biosekuritas sangat perlu untuk diperhatikan. Untuk itu, pembahasan pada makalah ini berkaitan dengan hal-hal tersebut.

\section{PEMILIHAN BENUR}

Benur vanamei yang berkualitas baik dilihat dari segi pertumbuhannya yaitu benur F1 dari induk asal Hawaii, namun demikian pengguna susah mendeteksi apakah benur vanamei yang dibeli dari panti benih tersebut merupakan F1 induk asal Hawaii atau F1 dari induk lokal. Perbedaan pertumbuhan kedua benur tersebut sudah banyak dilaporkan oleh para pakar pertambakan. Misalnya Anonim (2005) melaporkan bahwa benur vanamei F1 dari induk asal Hawai yang dibudidayakan dengan pola intensif pada umur 140 hari telah mencapai ukuran rata-rata 20,4 g; sedangkan pada benur dari induk lokal, setelah 140 hari pemeliharaan hanya mencapai ukuran 14,8 g. Kemudian dari pengalaman budidaya udang vanamei pola tradisional plus (Gunarto et al., 2006), penelitian pertama menggunakan benur yang didatangkan dari Anyer dengan ukuran PL-10 (Gambar 1A) yang ditebar dalam tambak penelitian Balai Riset Perikanan Budidaya Air Payau (BRPBAP), Maros benur yang lolos dan mampu bertahan hidup setelah serangan WSSV, hingga 100 hari pemeliharaan hanya mencapai ukuran rata-rata 10,6 g. Sedangkan pada penelitian kedua dengan pola teknologi yang sama menggunakan benur vanamei PL-22 (Gambar 1B) yang diambil dari panti benih di Sulawesi Selatan dan ditebar pada tambak yang sama untuk penelitian pertama, setelah 76 hari pemeliharaan telah mencapai ukuran ratarata $20--21 \mathrm{~g}$, meskipun dibudidayakan pada waktu salinitas tinggi 53--34 ppt. Dengan demikian yang perlu diperhatikan sebagai salah satu cara untuk mendapatkan benur yang sehat adalah sebagai berikut:

- Hindari faktor-faktor yang menyebabkan benur menjadi stres, misalnya mendatangkan benur dari panti benih jauh dari tambak yang memerlukan perjalanan lama (lebih dari satu hari). Apabila tidak dapat dihindari, maka sebaiknya benur dibuat tokolan terlebih dahulu supaya yang lemah terseleksi secara alami

- Gunakan benur yang sudah kuat artinya PL yang tua misalnya PL 20--25

- Benur juga harus bebas penyakit, misalnya dengan deteksi melalui tes PCR. Penyakit Infectious Hypodermal and Hematopoietic Necrosis Virus (IHHNV) yang menyerang vanamei menyebabkan benur tumbuh lambat dan terdapat variasi ukuran yang besar (Castille et al., 1993).

\section{PERSIAPAN TAMBAK SECARA MAKSIMAL}

Persiapan tambak untuk budidaya udang meskipun dengan pola tradisional plus juga harus dilakukan secara maksimal artinya bahwa harus betul-betul teliti, detil, dan tuntas jangan setengah-setengah pada segala aspek. Yang menyangkut persiapan tambak misalnya, dari perbaikan pematang untuk menghindari kebocoran, jangan sampai
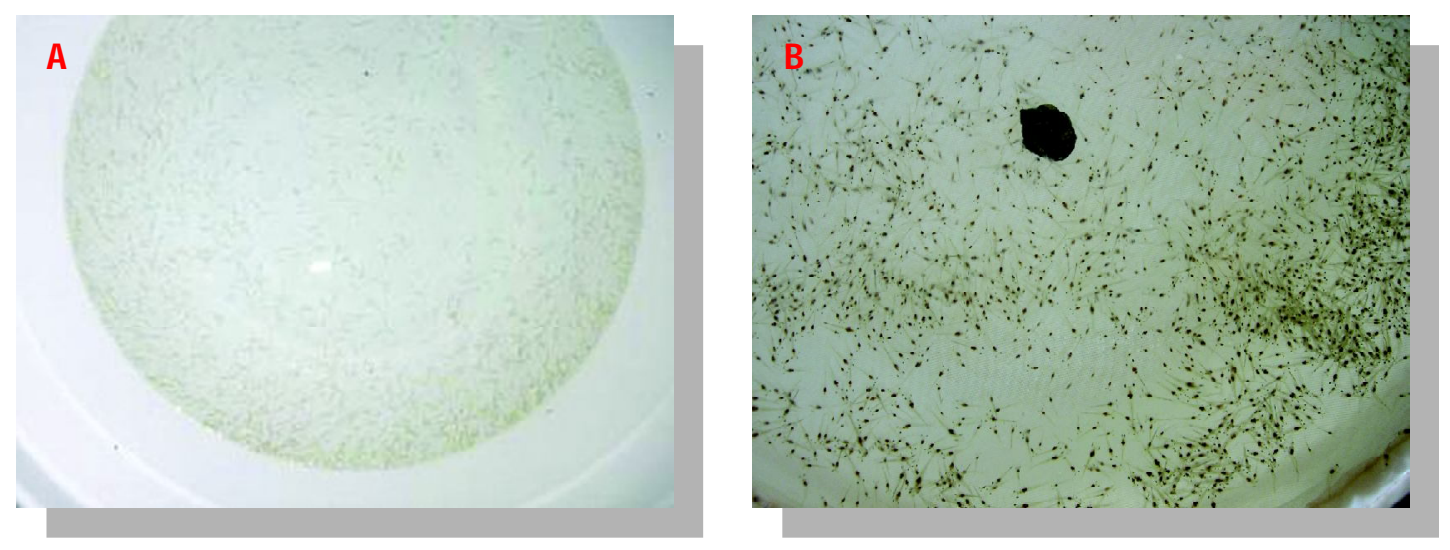

Gambar 1. Benur vanamei PL-10 dari panti benih di Banten (A), benur vanamei PL-22 dari panti benih di Sulawesi Selatan (B) 
masih ada yang bocor meskipun sedikit, sehingga tidak ada benih ikan lain yang masuk ke petakan tambak setelah digenangi air. Dalam hal pemberantasan hama, diusahakan ikan mujair, kakap, kepiting, ular juga termasuk trisipan harus betul-betul sampai mati atau habis semua termasuk telur-telurnya.

Pemberantasan jenis-jenis ikan dapat dilakukan dengan saponin atau serbuk biji teh dengan konsentrasi 5--10 $\mathrm{mg} / \mathrm{L}$. Efektivitas saponin tergantung pada salinitas dan cuaca. Pada salinitas di atas $25 \mathrm{ppt}$ dengan cuaca terik matahari, maka penggunaan saponin sebanyak $5 \mathrm{mg} / \mathrm{L}$ sudah aktif membunuh ikan hama yang ada dalam perairan tambak. Daya racun saponin akan terdegradasi dengan sendirinya setelah dua hari, dengan demikian daya bunuhnya terhadap ikan hama akan hilang setelah dua hari pemakaian di tambak. Ikan-ikan yang mati segera dikeluarkan dari tambak. Agar lebih hemat dalam pemakaian saponin sebaiknya dilakukan setelah pembuangan atau pengurangan air tambak, sehingga ikan hama akan terkumpul pada genangan air yang tersisa yang
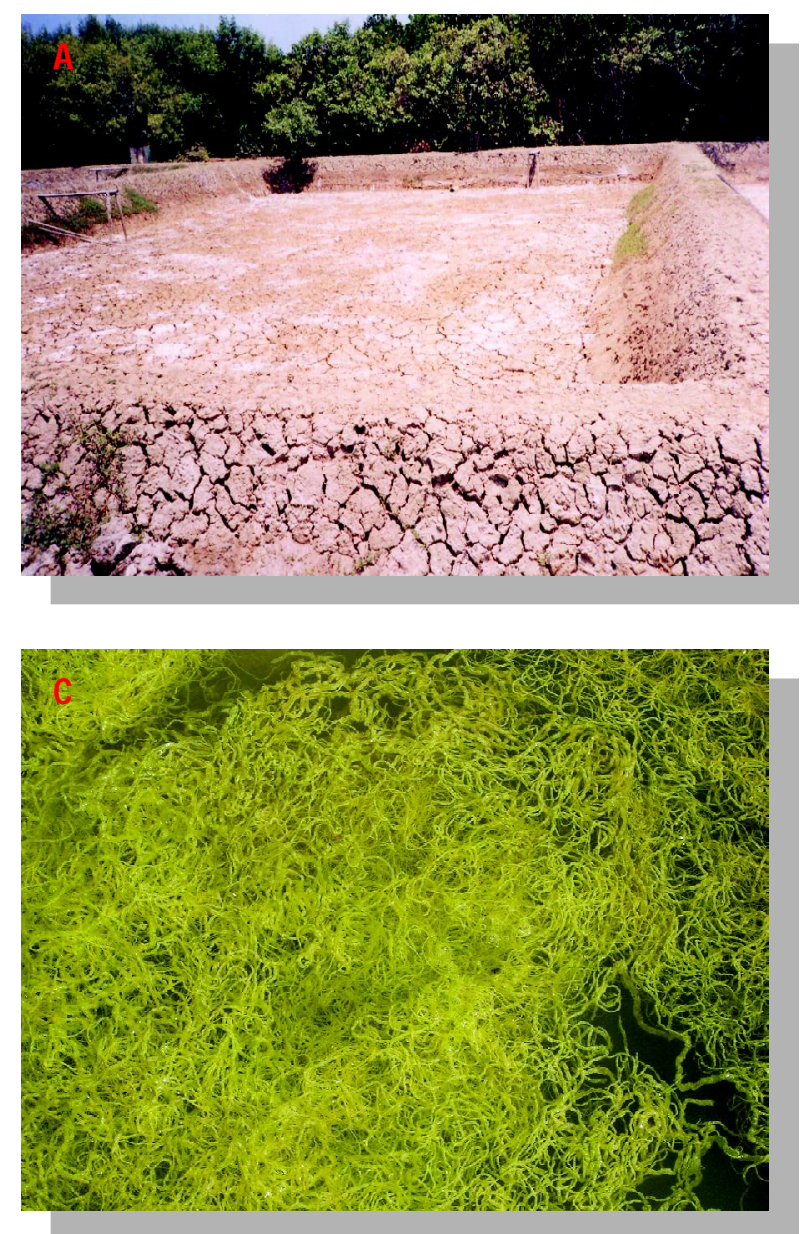

Gambar 2. Pengeringan tambak secara maksimal (A), tambak yang dibuat saluran tengah (B), lumut perut ayam yang tumbuh di pelataran tambak (C), tambak dengan plankton yang sehat (D) susah dibuang kecuali dihisap menggunakan pompa. Dengan demikian jumlah saponin yang digunakan menjadi lebih sedikit.

Pengeringan pelataran harus betul-betul kering semuanya sampai retak-retak (Gambar 2A). Di samping trisipan yang ada di permukaan tanah menjadi mati juga nilai redoks potensial menjadi positif dan disarankan paling rendah mencapai nilai +50 . Hal ini dimaksudkan agar penurunan nilai redoks potensial berjalan lambat setelah tambak dioperasionalkan. Dengan demikian penetrasi oksigen tetap sampai kedasar tambak, sehingga lingkungan dasar tambak tetap cocok untuk kehidupan udang yang dibudidayakan (Gunarto, 2006). Pengeringan secara total juga akan membunuh bakteri patogen dan menghilangkan zat-zat racun seperti $\mathrm{H}_{2} \mathrm{~S}$ yang ada pada sedimen tambak.

Perataan pelataran harus lebih rendah kearah pintu pipa pembuangan dan lebih tinggi di bagian pemasukan air, dibuatkan saluran tengah di pelataran tambak (Gambar 2B) bertujuan untuk memperlancar pembuangan kotoran
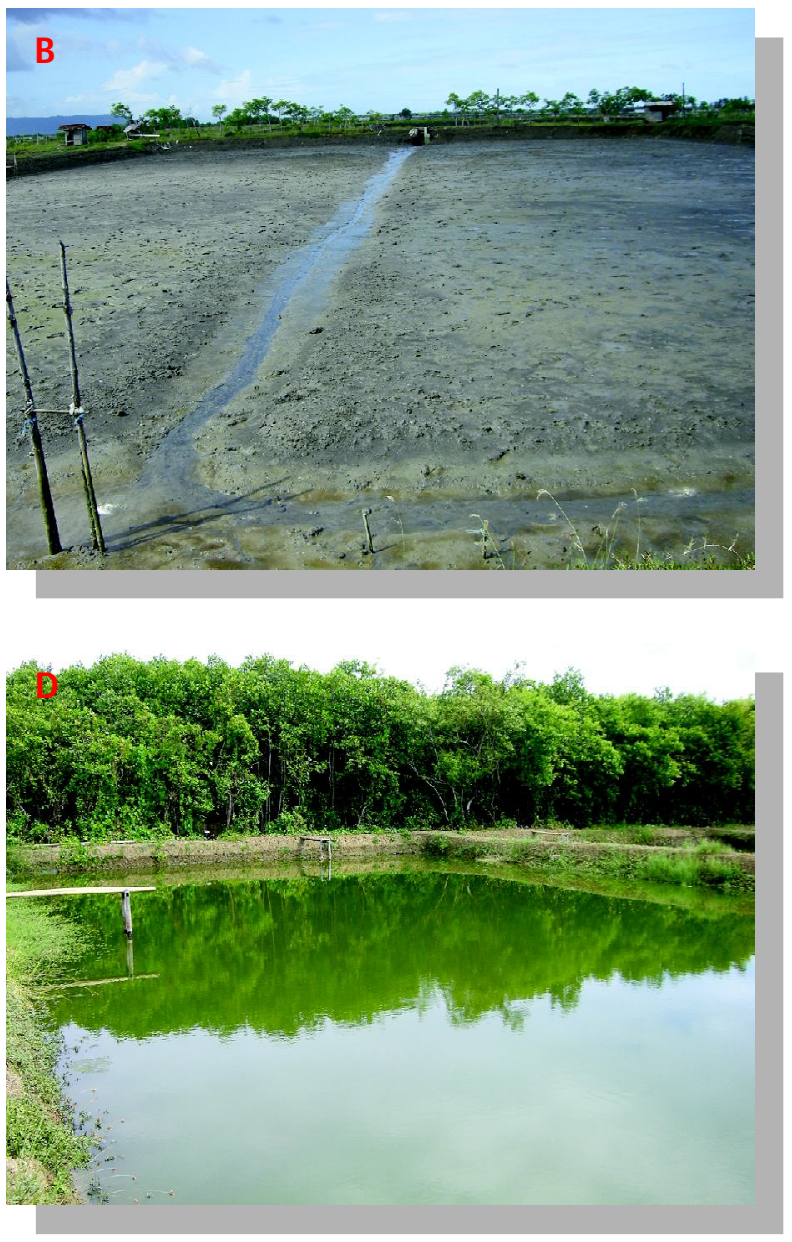
udang dan bahan organik lainnya yang dapat merusak kualitas air. Pemasangan saringan pada pipa pemasukan dan pembuangan harus kuat dan jangan sampai ada kebocoran, sehingga telur atau benih mujair tidak masuk ke tambak.

Pengapuran dasar tambak dilakukan pada saat dasar tambak masih lembab sehingga fungsi pengapuran akan efektif karena mampu meningkatkan $\mathrm{pH}$ tanah tambak. Kapur bakar yang digunakan sebanyak $600 \mathrm{~kg}$ pada $\mathrm{pH}$ tanah tambak yang normal, tetapi apabila pH tanah tambak asam maka jumlah kapur bakar yang diberikan akan semakin banyak.

Pemupukan dasar dimaksudkan untuk memperbaiki struktur tanah dasar dan menambah nutrien, sehingga pakan alami menjadi tumbuh baik. Untuk menjaga agar pakan alami yang tumbuh di tambak berkelanjutan maka dapat dilakukan pemupukan susulan dengan dosis $10 \%$ dari pupuk dasar. Pupuk dasar yang disarankan untuk pH tanah normal, dengan kandungan bahan organik 3\%-8\% adalah sebanyak $150 \mathrm{~kg}$ urea dan $75 \mathrm{~kg}$ SP-36/hektar. Pada pemupukan seperti itu maka pakan alami yang tumbuh didominasi oleh lumut usus ayam (Gambar 2C) dan pertumbuhan plankton cukup sehat (Gambar 2D).

\section{PENGELOLAAN AIR}

Satu di antara beberapa kunci yang menentukan keberhasilan budidaya udang di tambak yaitu pada teknik pengelolaan air yang dilakukan secara hati-hati dan penuh perhitungan. Hal ini karena banyaknya penyakit di sekitar lingkungan tambak, misalnya dari tambak tetangga yang udangnya sakit dan sewaktu-waktu dibuang airnya. Di samping itu, penyakit seperti WSSV (White Spot Syndrome Virus) juga dibawa oleh hewan carrier, misalnya trisipan, jembret, dan kepiting. Penyakit tersebut sewaktu-waktu dapat mengancam kesehatan udang yang dibudidayakan, karena dapat menyebabkan terjadinya ledakan penyakit diseases outbreak dan berakibat kematian massal pada udang yang dibudidayakan. Ledakan penyakit WSSV misalnya, akan terjadi apabila terdapat goncangan kualitas air yang melebihi kondisi normal (misalnya suhu, oksigen terlarut, amonia, nitrit) yang menyebabkan udang menjadi stres, maka penyakit akan mudah menyerang pada udang yang stres tersebut.

Sistem pengelolaan air yang hemat dan efektif dapat mencegah masuknya penyakit dari luar tambak adalah dengan sistem resirkulasi. Pada kondisi lapang yang bisa dilakukan yaitu dengan sistem resirkulasi semi tertutup artinya sistem resirkulasi tetapi masih tetap dilakukan penambahan air tidak hanya dari air buangan yang telah ditandon, tetapi sewaktu-waktu mengambil air dari saluran pada waktu air saluran dianggap baik. Hal ini dilakukan untuk menjaga ketinggian air akibat hilangnya air oleh rembesan ataupun penguapan.

Contoh tambak penelitian pola resirkulasi semi tertutup yang ada di Instalasi Tambak Penelitian Maranak (Gambar 3), menggunakan tambak ukuran $500 \mathrm{~m}^{2}$ sebanyak 12 unit, dan satu unit tandon mangrove $(2.000$ $\mathrm{m}^{2}$ ), serta dua unit petak tandon masing-masing ukuran $1.000 \mathrm{~m}^{2}$ (tandon I), dan $1.000 \mathrm{~m}^{2}$ (tandon pembuangan). Petak tandon mangrove bisa juga ditebari dengan tiram yang dipelihara dengan sistem rak, atau bisa ditambahkan gelondongan bandeng. Petak tandon I bisa ditebari rumput laut Gracillaria sp., petak tandon pembuangan juga bisa ditebari bandeng. Aliran air dimulai dari air sungai kemudian dimasukkan ke petak tandon mangrove, kemudian dialirkan ke tandon I yang berisi Gracillaria sp., selanjutnya air dimasukkan ke petak udang. Tinggi air dalam tambak pemeliharaan udang pola tradisional dengan sistem pemupukan pada kedalaman $80--90 \mathrm{~cm}$ terutama pada saat pasang, sedangkan saat surut (konda) tinggi air di petak tambak turun sampai hanya sekitar $60 \mathrm{~cm}$. Penggantian air dalam petak udang pada bulan kedua dan ketiga sebanyak 5\%-10\%terutama dilakukan pada saat air pasang tinggi. Air buangan dari petak udang dimasukkan ke tambak tandon pembuangan dalam beberapa hari dan selanjutnya air dialirkan ke petak mangrove. Model pengelolaan air ini disebut sebagai cara sirkulasi semi tertutup.

Kualitas air tambak menggunakan pola resirkulasi dengan sistem tandon dan penggantian air 1--2 kali pada setiap periode pasang sebanyak $5 \%-10 \%$ dari total volume air tambak, ternyata belum mampu mengurangi peningkatan kandungan BOT tambak sebagai akibat timbunan sisa pakan dan sisa metabolisme dari udang

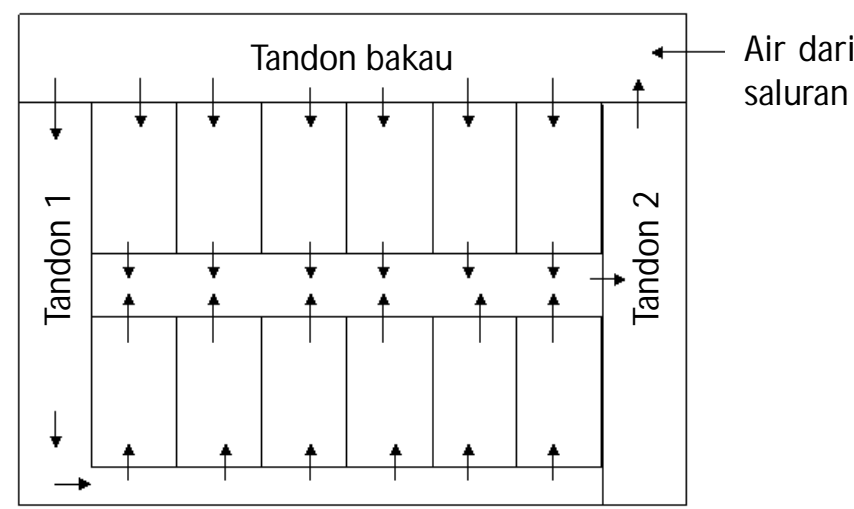

Gambar 3. Pola resirkulasi air pada pemeliharaan udang di tambak. (Tandon 1 = tandon rumput laut dan tandon $2=$ tandon pembuangan) 
yang dipelihara. Untuk menurunkan BOT agar lebih rendah, maka volume air yang diganti perlu ditingkatkan menjadi $10 \%$ dari volume total dan frekuensi penggantian air perlu ditambah pada setiap periode pasang yaitu dari 1--2 kali menjadi 3--4 kali, dan dilakukan pada saat air pasang sudah pada ketinggian yang maksimum.

Tiram dan bandeng sebagai hewan biofilter mampu menurunkan kandungan BOT dan total bakteri Vibrio sp. di semua air tambak tandon, tetapi dalam air tambak perlakuan masih terdapat kecenderungan peningkatan kandungan bakteri Vibrio sp. Hal ini kemungkinan karena kelebihan penggunaan pakan buatan yang diberikan ke udang juga sisa metabolisme seperti feses udang yang baik untuk media pertumbuhan bakteri patogen.

\section{PEMUPUKAN SUSULAN}

Keberhasilan pemeliharaan udang di tambak semi intensif dan ekstensif sangat ditentukan oleh ketersediaan pakan alami. Pakan alami di tambak didominasi oleh detritus, sisa binatang, diatom, cianobacteria, dan alga hijau (Bombeo-Tuburan et al., 1993). Kontribusi pakan alami termasuk fitoplankton pada udang yang dibudidayakan yaitu melalui rantai makanan, di mana udang makan makrofauna seperti kekerangan yang kecil, gasteropoda, meiofauna misalnya polychaeta, amphipoda dan harpaticoid copepo da serta pada meio benthos seperti bakteria dan detritus (Rodríguez \& Osuna, 2003). Untuk peningkatan pakan alami di tambak dapat dilakukan dengan cara pemupukan. Menurut Amin et al. (1992), pemupukan dimaksudkan sebagai usaha pemberian nutrien kedalam tanah atau tambak dengan tujuan untuk meningkatkan daya dukung perairan guna menghasilkan pakan alami bagi makroorganisme.

Menurut Huet (1978), dengan melakukan pemupukan susulan secara periodik dalam jumlah tertentu kedalam perairan akan merangsang pertumbuhan fitoplankton sehingga mempengaruhi kesuburan perairan. Selain plankton yang tumbuh di tambak terdapat juga berbagai jenis bakteri. Bakteri patogen yang berbahaya dan dapat menyebabkan gagal panen adalah bakteri Vibrio harveyi di mana pada konsentrasi $10^{3} \mathrm{cfu} / \mathrm{mL}$ di air dapat menstimulir mewabahnya WSSV pada udang, sehingga menyebabkan gagal panen. Oleh karena itu, untuk menekan peningkatan populasi Vibrio sp., biasanya digunakan fermentasi probiotik yang banyak mengandung bakteri Bacillus sp. yang mempunyai kemampuan untuk mengurai bahan organik, sehingga media untuk tumbuhnya bakteri patogen menjadi berkurang $\left(<10^{2} \mathrm{cfu} / \mathrm{mL}\right)$.

Pada percobaan pemupukan susulan masing-masing sebanyak 0 (A); 5 (B); 7,5 (C); dan 10\%(D) dari pupuk dasar, diperoleh bahwa pemupukan susulan yang diaplikasikan $10 \%$ dari pupuk dasar memberikan pertumbuhan udang yang relatif lebih cepat daripada pemberian pupuk susulan yang lain.

Dari Gambar 4 tengah, nampak bahwa populasi bakteri Vibrio sp. di air paling tinggi pada semua perlakuan pada kepadatan $10^{3} \mathrm{cfu} / \mathrm{mL}$ yaitu terjadi pada awal penebaran dan selanjutnya berfluktuasi. Nampak bahwa ada keterkaitan antara populasi mikroplankton (gabungan antara fitoplankton dan zooplankton) (Gambar 4 atas) dengan populasi bakteri Vibrio sp. (Gambar 4 tengah) di air, di mana apabila dijumpai populasi plankton tinggi, maka populasi bakteri rendah seperti yang terlihat di perlakuan B, C, dan D. Sedangkan apabila populasi plankton rendah seperti pada perlakuan $\mathrm{A}$ (kontrol) tanpa pemupukan susulan, maka populasi bakteri Vibrio sp. di air tinggi. Begitu juga populasi bakteri Vibrio sp. di
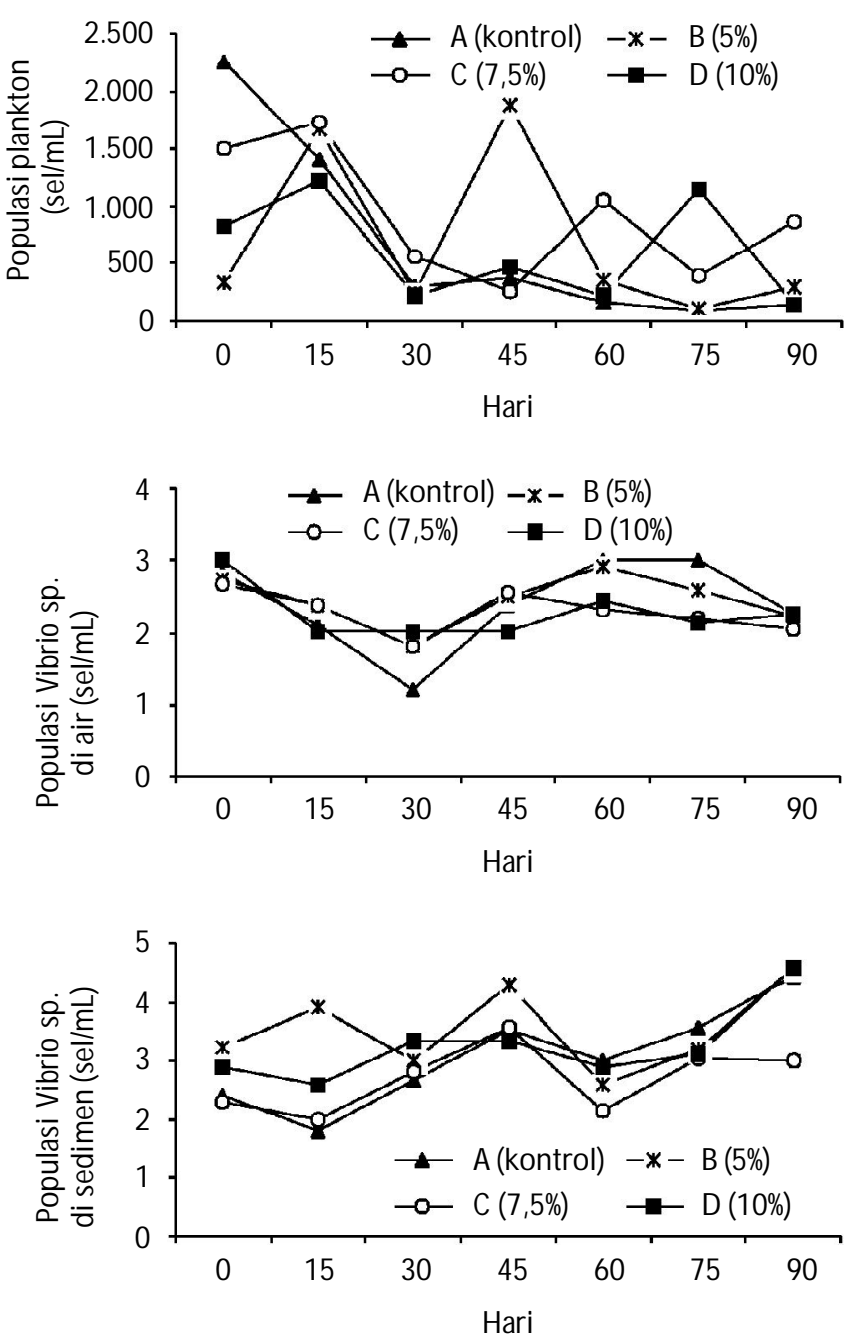

Gambar 4. Populasi plankton (atas), bakteri Vibrio sp. di air (tengah), dan di sedimen tambak (bawah) (Sumber: Gunarto \& Nurbaya, 2007) 
sedimen tambak nampak terdapat keterkaitannya antara populasi plankton di air dan populasi Vibrio sp. di sedimen tambak, meskipun tidak begitu kentara. Namun demikian nampak bahwa di sedimen tambak, semakin lama pemeliharaan udang di tambak berlangsung, maka populasi Vibrio sp. semakin tinggi yaitu dari $10^{2} \mathrm{cfu} / \mathrm{mL}$ pada awal penelitian meningkat mencapai $10^{4} \mathrm{cfu} / \mathrm{mL}$ pada hari ke90 pada perlakuan A (kontrol) dan perlakuan pemupukan $B$ dan $D$. Hal ini karena meskipun dilakukan pemupukan tetapi populasi plankton kurang meningkat secara tajam.

Terjadinya penekanan Vibrio sp. yang tidak signifikan baik di air maupun di sedimen tambak pada penelitian ini disebabkan oleh rendahnya populasi mikroplankton di semua perlakuan yang menggunakan pemupukan susulan maupun kontrol, di mana populasi plankton tertinggi hanya mencapai $2 \times 10^{3} \mathrm{sel} / \mathrm{mL}$. Menurut Lio-Po et al. (2005), populasi fitoplankton yang efektif mengeluarkan anti-luminious Vibrio adalah kepadatan $10^{5} \mathrm{sel} / \mathrm{mL}$, terutama spesies Chaetoceros sp., Nannochlorum sp., Nitzchia sp., Skeletonema sp., dan Leptolyngbia sp. Blooming fitoplankton akibat pengkayaan nutrien di tambak apabila kepadatan fitoplankton mencapai $10^{6} \mathrm{sel} / \mathrm{mL}$.

Beberapa jenis plankton di tambak telah dilaporkan ada yang menguntungkan ataupun merugikan bagi kesehatan udang terutama pada saat blooming. Blooming dinoflagellata jenis Peridinium balechii kurang membahayakan pada udang, sedangkan Gonyaulax tamarensis, Gymnodinium, Gyrodinium instriatum masing-masing menyebabkan kematian udang windu di Taiwan, China, dan Ekuador. Kasus kematian udang di Malaysia pada tahun 1982--1985, karena alga Raphidophyta genus Hornelia, alga ini menghasilkan lapisan seperti sutera yang dapat menutupi insang udang sehingga menjadi berwarna coklat.

Berdasarkan kemampuan fitoplankton untuk menghambat perkembangan populasi Vibrio harveyi, maka disarankan dalam budidaya udang untuk menumbuhkan fitoplankton terlebih dahulu sebelum dilakukan penebaran. Selanjutnya diupayakan menjaga populasi fitoplankton agar tetap berkesinambungan sepanjang pemeliharaan.

\section{PENGGUNAAN PROBIOTIK}

Probiotik telah banyak digunakan, satu di antaranya untuk menjaga kondisi lingkungan tambak agar tetap layak dan optimal untuk kehidupan udang. Moriarty (1998) melaporkan bahwa telah berhasil menekan populasi bakteri Vibrio harveyi pada sedimen tambak menggunakan bakteri Bacillus spp. Pengaruh bakteri probiotik tersebut terhadap udang tidak langsung karena kemampuan Bacillus spp. untuk mendekomposisi bahan organik, sehingga mampu memperbaiki kualitas air tambak. Menurut Hirota et al., 1995 dalam Maeda (1999), keberadaan B. subtillis dalam lapisan sedimen yang anaerob dapat mengakibatkan konsentrasi sulfida menurun sehingga redoks potensial (Eh) menjadi meningkat yang mengindikasikan peningkatan kualitas kondisi sedimen tambak. Sedangkan Devaraja et al. (2002) mengemukakan bahwa penggunaan probiotik tidak mempunyai efek yang berlawanan dengan bakteri yang normal yang berada dalam tambak, tetapi akan meningkatkan populasi bakteri mineralisasi sehingga terjadi percepatan proses dekomposisi.

Penggunaan probiotik akan menambah biaya produksi karena harga di pasaran cukup mahal. Hal ini bisa ditekan dengan cara diperbanyak terlebih dahulu menggunakan bahan-bahan tertentu, misalnya campuran dedak halus, tepung ikan, molase, dan probiotik dengan perbandingan tertentu sehingga mampu meningkatkan populasinya. Dengan demikian harga probiotik menjadi lebih murah dan efisien. Pada kultur massal dengan media tepung ikan, nampak bahwa pada hari kedua populasi bakteri probiotik telah mencapai $10^{9} \mathrm{CFU} / \mathrm{mL}$ bahkan sampai level $10^{12} \mathrm{CFU} /$ $\mathrm{mL}$ (Gunarto et al., 2005). Menurut Maeda (1999), sterilisasi media air dan kecukupan bahan organik terlarut di dalam air untuk kultur massal dapat meningkatkan populasi bakteri yang cukup tinggi.

Cara untuk memperbanyak populasi bakteri probiotik dapat digunakan prosedur dari Poernomo (2004) yang bahannya terdiri atas dedak halus $=5 \mathrm{~kg}$; tepung ikan $=$ $2,5 \mathrm{~kg}$; molase $=2,5 \mathrm{~L}$; probiotik $=2 \mathrm{~L}$; marine yeast $=$ $100 \mathrm{~g}$; dan air payau= $80 \mathrm{~L}$. Prosedur pembuatan medianya adalah sebagai berikut:

Rebus air payau 80 liter sampai mendidih, masukkan dedak halus dan tepung ikan, diaduk 0,5--1 jam, masukkan molase, diaduk dan didinginkan. Tambahkan yeast $100 \mathrm{~g}$ dan probiotik 2 liter, simpan selama 3 hari, ditutup renggang dan diaerasi adonan siap dipakai.

Pemakaian yang disarankan pada budidaya udang vanamei pola tradisional plus yaitu sebanyak $2--3 \mathrm{mg} / \mathrm{L}$ setiap minggu. Yang perlu diperhatikan di sini yaitu aplikasi fermentasi probiotik hendaknya jangan bersamaan dengan aplikasi pupuk susulan, tetapi minimal selang tiga hari setelah aplikasi pupuk susulan untuk menghindari penimbunan nutrien yang dapat berakibat menurunnya kandungan oksigen di perairan tambak. Keadaan tersebut dapat dimonitor terutama pada waktu pagi hari di mana udang berenang di permukaan. Apabila keadaan terjadi demikian maka segera ganti air tambak. 


\section{PENERAPAN BIOSEKURITAS}

Munculnya istilah biosekuritas pada budidaya udang adalah setelah ada kejadian mewabahnya berbagai penyakit yang menyebabkan kematian massal pada udang di tambak. Biosekuritas pada awalnya hanya diterapkan di panti benih karena keberadaan larva yang rentan penyakit, sehingga harus betul-betul dijaga kebersihan lingkungan panti benih. Namun dengan munculnya penyakit WSSV, MBV yang sangat ganas menyerang udang di tambak dan gampang menular, maka di tambak pun harus menerapkan biosekuritas untuk menjaga agar udang aman dari serangan penyakit. Telah diketahui bahwa hewan seperti jembret, kepiting, dan ikan mujair juga merupakan carrier WSSV, demikian pula burung, di mana kalau ada udang yang sakit, mereka akan beterbangan dan berkerumun di atas tambak tersebut dan sesekali turun untuk memangsa udang yang sakit.

Kadang-kadang dijumpai burung yang terbang sambil mencocok udang yang sakit sehingga kalau udang yang sakit tersebut jatuh ke tambak udang yang sehat, maka biasanya udang di tambak tersebut dalam satu minggu akan segera tertular serangan WSSV. Penggunaan alat, misal jala untuk sampling harus dipisahkan dengan jala yang digunakan untuk mencari ikan oleh penggarap tambak. Hal ini untuk menghindari kontaminasi alat dari penyakit yang dapat menyerang udang yang dibudidayakan. Pemasukan air ke tambak juga harus dengan strategi, tetapi harus melihat apakah air pasang sudah tinggi maksimal. Apabila air pasang sudah tinggi dan maksimal berarti air ini berasal dari laut, bukan air buangan dari tambak tetangga. Dengan banyaknya penyakit di sekitar perairan pantai, maka penggantian air tidak boleh terlalu sering dan juga dengan persentase yang rendah yaitu hanya $5 \%-10 \%$ dari volume total.

\section{PENERAPAN BEBERAPA ASPEK PENTING DALAM PELAKSANAAN PENELITIAN BUDIDAYA VANAMEI}

Pada bulan September hingga Desember 2006 dengan menggunakan tambak ukuran $500 \mathrm{~m}^{2} /$ petak sebanyak 12 petak telah dilakukan penelitian budidaya udang vanamei menggunakan sistem pemupukan susulan. Sebelum
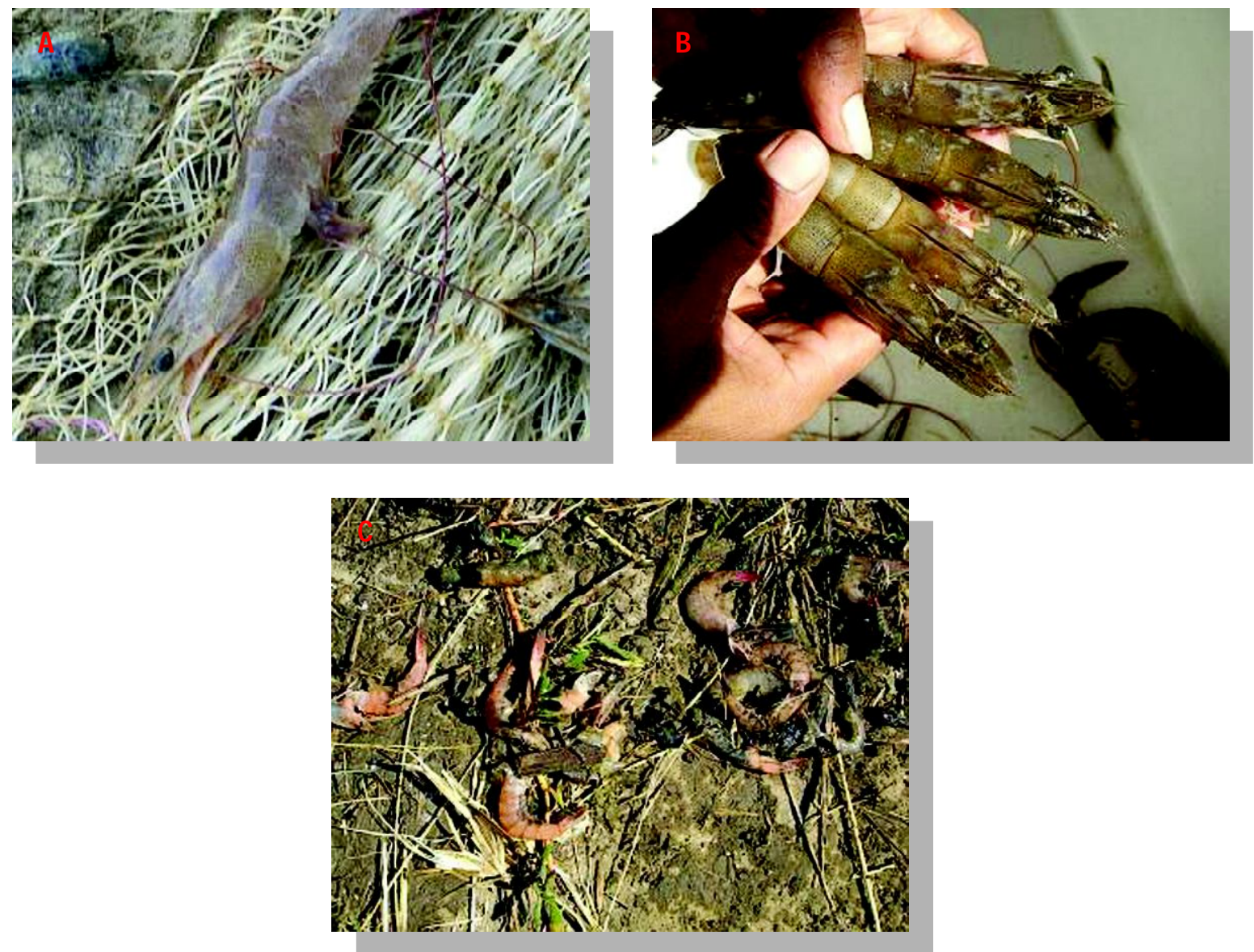

Gambar 5. Udang vanamei yang masih hidup tetapi sudah terserang WSSV, nampak tubuhnya kemerahan (A), udang vanamei yang terserang WSSV dengan bintik putih di karapas (B), udang vanamei yang mati akibat serangan WSSV (C) 
penebaran dilakukan persiapan tambak, tidak ada pemupukan awal tetapi langsung dilakukan pemupukan sesuai dosis untuk pemupukan susulan yaitu $750 \mathrm{~g}$ urea dan $375 \mathrm{~g} \mathrm{SP}-36 / 500 \mathrm{~m}^{2}$. Penebaran benur vanamei PL-22 dilakukan seminggu kemudian, dengan padat tebar berbeda sebagai perlakuan yaitu 1, 3, 5, dan 7 ekor $/ \mathrm{m}^{2}$. Masing-masing perlakuan dengan tiga kali ulangan. Selanjutnya pemupukan susulan diberikan dengan dosis yang sama satu minggu sekali, pada bulan pertama pemeliharaan. Ketinggian air pada level $70--80 \mathrm{~cm}$. Pada bulan kedua dan ketiga pemupukan susulan diberikan antara 1--2 minggu sekali dengan dosis yang sama, tergantung pada warna air, melimpahnya klekap atau lumut yang tumbuh di pelataran tambak. Kalau lumut atau plankton tumbuh padat maka pemupukan susulan dihentikan untuk sementara, kemudian dicek nilai $\mathrm{pH}$ apabila melebihi nilai 9, maka air tambak sebagian dibuang untuk diganti dengan air baru yang diambil dari tandon. Penggantian air mulai dilakukan pada bulan kedua dan ketiga dengan cara membuang air sebanyak 5\%-10\%dari volume total air dalam setiap petak tambak.

Di samping itu, dilakukan juga pemberian fermentasi probiotik (Poernomo, 2004) sebanyak $3 \mathrm{mg} / \mathrm{L}$ dengan cara dihambur merata ke seluruh perairan tambak dengan frekuensi satu minggu satu kali dimulai setelah satu minggu pemeliharaan hingga menjelang panen. Agar tidak terjadi penimbunan nutrien ataupun peledakan populasi plankton yang diakibatkan oleh pemupukan susulan dan penambahan fermentasi probiotik, maka pemberian fermentasi probiotik dilakukan selang tiga hari setelah pemupukan. Penambahan probiotik dan pemupukan dalam selang waktu berdekatan biasanya menyebabkan menurunnya kandungan oksigen terlarut hingga $2 \mathrm{mg} / \mathrm{L}$, terutama pada waktu pagi hari. Dengan demikian perlu dilakukan pengecekan terhadap kondisi udang setiap pagi hari antara pukul 6--7 pagi. Apabila kandungan oksigen terlarut rendah, maka udang akan melayang-layang di permukaan air. Apabila terjadi keadaan demikian maka segera ganti dan tambahkan air dari tandon. Pertumbuhan, produksi, dan sintasan udang selama penelitian dapat dilihat pada Tabel 1.

Berdasarkan Tabel 1 nampak bahwa pertumbuhan udang pada kepadatan 1, 3, dan 7 ekor/m² cukup cepat yaitu mencapai ukuran rata-rata 20--21 g selama 76 hari pemeliharaan dan tidak ada perbedaan yang signifikan $(P>0,05)$ di antara perlakuan tersebut. Namun ketiganya berbeda nyata $(P<0,05)$ dengan pertumbuhan udang di perlakuan C (5 ekor $\left./ \mathrm{m}^{2}\right)$. Udang di perlakuan $\mathrm{C}$ tumbuh lambat karena banyaknya mujair dan trisipan di petak tersebut, yang merupakan kompetitor pakan alami. Dibandingkan dengan pertumbuhan udang vanamei pada pola semi intensif yang hanya mencapai rata-rata 13,03 g selama 100 hari pemeliharaan (Mangampa, 2007), maka pertumbuhan udang pada penelitian ini jauh lebih besar.

\section{KESIMPULAN}

Budidaya udang vanamei di tambak dengan pola tradisional plus dikerjakan secara teliti di antaranya dalam hal persiapan tambak: pemilihan dan penanganan benur, kontruksi tambak, pengelolaan air secara cermat

Tabel 1. Rata-rata berat akhir, produksi kelekap, produksi udang, dan sintasan udang vanamei yang dibudidayakan di tambak selama 76 hari

\begin{tabular}{|c|c|c|c|c|c|c|c|}
\hline Perlakuan & $\begin{array}{c}\text { Rata-rata } \\
\text { bobot } \\
\text { awal } \\
\text { (g) }\end{array}$ & $\begin{array}{c}\text { Rata-rata } \\
\text { kandungan } \\
\text { klorofil-a } \\
(\mu \mathrm{g} / \mathrm{L})\end{array}$ & $\begin{array}{c}\text { Rata-rata } \\
\text { produksi } \\
\text { kelekap } \\
\left(\mathrm{g} / \mathrm{cm}^{2}\right)\end{array}$ & $\begin{array}{l}\text { Rata-rata } \\
\text { bobot } \\
\text { akhir } \\
\text { udang } \\
\text { (g/ekor) }\end{array}$ & $\begin{array}{c}\text { Rata-rata } \\
\text { produksi udang } \\
\left(\mathrm{kg} / 500 \mathrm{~m}^{2}\right) \\
\text { Kisaran produksi } \\
\text { per hektar } \\
(\mathrm{kg} / \mathrm{ha})^{*}\end{array}$ & $\begin{array}{c}\text { Rata-rata } \\
\text { sintasan } \\
(\%)\end{array}$ & $\begin{array}{c}\text { Kisaran } \\
\text { jumlah } \\
\text { udang } \\
\text { dipanen } \\
\text { per petak } \\
\left(\text { ekor } / 500 \mathrm{~m}^{2} \text { ) }\right.\end{array}$ \\
\hline A $\left(1 \mathrm{ekor} / \mathrm{m}^{2}\right)$ & 0,2 & $9,99 \pm 7,57^{\mathrm{a}}$ & $1,35 \pm 0,95^{\mathrm{a}}$ & $21,63 \pm 3,17$ & $\begin{array}{c}4,75 \pm 3,66^{\mathrm{a}} \\
(82-173,8)\end{array}$ & $60,35 \pm 34,68^{\mathrm{a}}$ & $57-494$ \\
\hline B (3 ekor $\left./ \mathrm{m}^{2}\right)$ & 0,2 & $10,840 \pm 8,08^{\mathrm{a}}$ & $1,46 \pm 1,02^{\mathrm{a}}$ & $20,11 \pm 2,86$ & $\begin{array}{c}9,75 \pm 1,03^{b} \\
(174-214)\end{array}$ & $31,57 \pm 5,53^{\mathrm{a}}$ & $393-559$ \\
\hline C $\left(5\right.$ ekor $\left./ \mathrm{m}^{2}\right)$ & 0,2 & $13,57 \pm 12,82^{\mathrm{a}}$ & $1,65 \pm 1,08^{\mathrm{a}}$ & $12,38 \pm 7,30$ & $\begin{array}{l}7,87 \pm 3,23^{\mathrm{a}} \\
(175,6-211)\end{array}$ & $32,07 \pm 25,19^{a}$ & $330-1.517$ \\
\hline $\mathrm{D}\left(7 \mathrm{ekor} / \mathrm{m}^{2}\right)$ & 0,2 & $10,29 \pm 7,65 a$ & $1,86 \pm 1,40^{\mathrm{a}}$ & $21,09 \pm 3,26$ & $\begin{array}{c}13,63 \pm 3,3^{b} \\
(232-350)\end{array}$ & $18,94 \pm 7,70^{b}$ & $508-973$ \\
\hline
\end{tabular}

Keterangan:

Angka dalam kolom yang sama diikuti huruf yang sama menunjukkan tidak berbeda nyata pada taraf kepercayaan $95 \%$

$*$ nilai konversi 


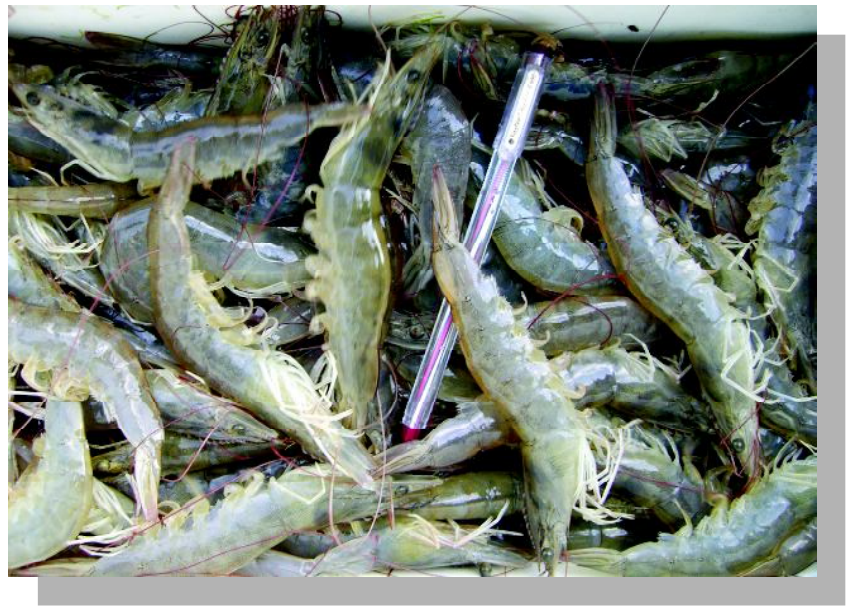

Gambar 6. Udang vanamei hasil panen dengan teknik budidaya menggunakan sistem pemupukan susulan

ditambah dengan pemupukan serta penggunaan fermentasi probiotik secara rutin setiap minggu serta upaya peningkatan biosekuritas di sekitar lingkungan tambak; akan dihasilkan udang dengan pertumbuhan yang lebih baik daripada pola semi intensif yang biasa dikerjakan petambak.

\section{SARAN}

Budidaya udang vanamei pola tradisional plus dengan teknis pemupukan susulan dapat dikembangkan untuk mendukung program revitalisasi tambak dengan syarat harus menerapkan seluruh aspek penting di atas agar dapat berhasil dengan baik.

\section{DAFTAR PUSTAKA}

Akiyama, D. 2005. World Shrimp Production and Current Issues. Makalah dipresentasikan pada Seminar Nasional Udang di Hotel Sahid, Makassar, 2 Mei 2005. $48 \mathrm{pp}$.

Amin, M. dan Wikanta. 1989. Percobaan pendahuluan pemupukan susulan pada pemeliharaan udang windu (Penaeus monodon) di tambak. Laporan Penelitian. Balai Penelitian Budidaya Pantai, Maros. 5 pp.

Amin, M., Suwardi, dan S. Amini. 1992. Rasio urea dan TSP sebagai pemupukan susulan pada budidaya udang windu, Penaeus monodon di tambak. J. Pen. Bud. Pantai. 8(4): 86-91.

Andarias, I. 1991. Pengaruh Pupuk Urea dan TSP terhadap Produksi Klekap. Disertasi. Fakultas Pascasarjana, IPB., Bogor. 155 pp.

Anonim. 2005. Aktualisasi pembenihan udang dalam menunjang perkembangan budidaya udang Indonesia. Masyarakat Akuakultur Indonesia (Team). Sekretariat:
Gedung Widya Puraya Lt. II, Kampus UNDIP Tembalang Semarang 50275 (Pusat Penelitian dan Pengembangan Teknologi). 14 pp.

Bombeo-Tuburan, I., N.G. Jr. Guanzon, and G.I. Schroeder. 1993. Production of Penaeus monodon (Fabricius) using four natural food types in extensive system. Aquaculture. 112: 57-65.

Castille, F.L., T.M. Samocha, A.L. Lawrence, H. He, P. Frelier, and F. Jaenike. 1993. Variability in growth and survival of early postlarval shrimp (Penaeus vanamei Boone 1931). Aquaculture. 113: 65-81.

Devaraja, T.N., F.M. Yusoff, and M. Shariff. 2002. Changes in bacterial populations and shrimp production in ponds treated with commercial microbial products. Aquaculture. 206: 245-256.

Gunarto, Bunga Rante T., E. Susianingsih, dan Muliani. 2005. Pemeliharaan benur windu (Penaeus monodon) di laboratorium dengan penambahan probiotik hasil perbanyakan. Makalah disajikan pada Seminar Nasional Kongres Biologi XIII di UGM Yogyakarta, 16--17 September 2005. 10 pp.

Gunarto, A.M. Tangko, B.R. Tampangalo, dan Muliani. 2006. Budidaya udang windu (Penaeus monodon) di tambak dengan penambahan probiotik. Jurnal Riset Akuakultur. 1(3): 303-313.

Gunarto, M. Amin, Muslimin, dan S. Tonnek. 2006. Pembesaran udang vanamei melalui dosis dan frekuensi pemupukan susulan berbeda. Laporan Teknis Penelitian TA 2006. Balai Riset Perikanan Budidaya Air Payau. 36 pp.

Gunarto. 2006. Apakah nilai reduksi dan oksidasi potensial sedimen tambak berpengaruh terhadap produksi udang windu di tambak? . M edia Akuakultur. 1(3): 9196.

Gunarto dan Nurbaya. 2007. Hubungan antara populasi mikroplankton dengan total bakteri Vibrio sp. pada budidaya udang vanamei dengan dosis pemupukan berbeda. Prosiding Seminar Nasional Kelautan III, Universitas Hang Tuah Surabaya, Komisi B, Budidaya: Pakan dan Penyakit. p. 35- 39.

Huet, M. 1978. Texbook of fish culture: breeding and cultivation of fish. Fishing Press, Inc., Queson City, Philippines. $436 \mathrm{pp}$.

Lio-Po G.D., E.M. Leano, M.M.D. Penaranda, A.U. VillaFranco, C.D. Sombito, and Jr. N.G. Guanzon. 2005. Anti-luminous Vibrio factors associated with the "green water" grow-out culture of the tiger shrimp Penaeus monodon. Aquaculture. 250: 1-7.

Maeda, M. 1999. Microbial processes in aquaculture. National Research Institute of Aquaculture Nansei, 
Japan. 102 pp.

Mangampa, M. 2007. Pengaruh penggunaan benih tokolan pada budidaya udang vanamei semi intensif. Prosiding Seminar Nasional Kelautan III, Universitas Hang Tuah Surabaya, Komisi A, Budidaya: Reproduksi. p. 3542.

Poernomo, A. 2004. Teknologi probiotik untuk mengatasi permasalahan tambak udang dan lingkungan budidaya.
Makalah disajikan pada simposium nasional tentang Perkembangan IImu dan Teknologi Inovasi dalam bidang Akuakultur, pada tanggal 27-29 Januari 2004 di Semarang. 20 pp.

Rodriguez, R.A. dan F.P. Osuna. 2003. Nutrients, phytoplankton and harmful algal blooms in shrimp ponds: a review with special reference to the situation in the Gulf of California. Aquaculture. 219: 317- 336. 